\title{
The Significance of Employability Training Courses According to Graduate Views: Empirical Research for \\ Greece
}

\author{
Andreas Dimopoulos \\ PhD Candidate Department of Economics Democritus University of Thrace \\ PO Box 3118, Fragma Thermis Post Code 57001, Thessaloniki Greece \\ E-mail: job1j@yahoo.gr; info@andreasdimopoulos.gr
}

\author{
Andreas Dimopoulos (Corresponding author) \\ Faculty of Social, Political, and Economics Sciences-Department of Economics, \\ Democritus University of Thrace \\ Panepistimioupoli, Komotini 69100, Greece \\ E-mail: secr@econ.duth.gr
}

Received: April 25, 2019 Accepted: May 27, 2019 Online published: May 30, 2019

doi:10.5296/ijhrs.v9i2.14864 URL: https://doi.org/10.5296/ijhrs.v9i2.14864

\begin{abstract}
There is a consensus that employability isn't only gathering degrees and other qualifications but rather is a set of various factors such as possessing the right transferable skills, the knowledge of job market, the combination of personal attributes, the ongoing training, self presentation skills, networking and ego drive to navigate yourself effectively in a continuous changing world of work. On the other hand, there is an opinion in general that graduates have a remarkable problem to enter the job market for the first time. They don't know how to search effectively for new job positions, how to present their skills and abilities towards the recruiters or employers and have no idea how to react in the interview process. Finally, employee candidates after graduation need help and consultancy to enter the job market.

This study aims to search the role of training courses in enhancing candidates' employability outcomes according to their opinion. For this purpose, an empirical research has been conducted in order to explore the view of the candidates' about the importance of relative courses to enhance their employability. In particular we asked two hundreds and thirteen post
\end{abstract}


graduates students in Greece about their opinion of the usefulness in participating and attaint such courses. Furthermore, combined we asked them how much they agree with particular statements that employability is more than having someone qualifications.

Results show that employability training courses could contribute effectively in employability outcomes .Also participants agree to the statements that to be someone employable depends not only on their qualifications but also on other factors such as the effectiveness of utilizing job search methods, self promotion skills, networking etc.

Keywords: employability, training course, job search, interview, employment, graduates

JEL codes: M53, M51, M12, J23, J24, J48, J64, 015, I23, I28

\section{Introduction}

The process of transition from the stage of study to the labor market specifically for young people is of particular importance for employability. The growing pace of university graduates and the increasing unemployment of them in many countries makes this transition a particularly tangible phenomenon in the labor market, which is increasingly in the public interest and is of great concern (Teichler, 1998; Teichler 2000, ILO, 2004). In the same way, the transition from study to the world of work is a matter of increasing interest also for students. How to find a job after studies is obviously a great concern, care for today's students, which dictates their international student choices to a great extent (Nilsson \& Ripmeester, 2016). In general, candidates who have just graduated from universities when looking for the first job in their careers do not own, nor are they equipped with the transferable competencies, skills which employers require from them (Davies, 2000). In most cases, candidates appear on the job market with only a very little knowledge of how to portray the most important thing they possess, that is to say themselves (Kitchen, 1994). Many new jobseekers are unaware of, or lack the skills to demonstrate the tough skills employers are looking for, even in case they posses them (ILO, 2013). Graduates at the end of their studies have a great difficulty and are struggling to make their next step in the labor market. They need help finding a job while they feel unprepared or poorly prepared for the labor market. They also anticipate more counseling from their university to make the transition from study to the world of work (Pollock, 2014)

Problem statement: it is obvious that graduates facing remarkable problems during their transition from studies to employment due to many different reasons such as lack of knowledge of the labor market, mismatch of necessary skills, lack of self confidence and effective presentation skills, insufficient preparation for job search and employment interview demands. Moreover according to literature review there is evidence that successful transition from studies to employment depends not only to formal qualifications but also on other factors such as job search effective skills, self presentation skills, impression management tactics, consulting and training. Thus this study aims to investigate and to support these theories in Greece considering the opinion of Greek graduates regarding the importance of a relative training in their anticipated employment positive outcomes. 


\subsection{Different Aspects of Employability and Factors Which Affect it}

Although employability as a concept has greatly already attracted attention and academic dialogue in the relevant literature, there are still significant gaps in the evidence linking the successful status of work readiness on employability of graduates, including the long-term impact in general on their careers (Rowe, 2017). Despite the fact that several surveys have studied the question of employability, however, there is no overall finding on this issue because, among other things, it has been shown that the different stakeholders involved in employability, such as policy makers, teaching staff and universities students, interpret this concept in a different way (Wickramasinghe \& Perera, 2010). The perceptions about the concept of employability have been broadened in recent years by focusing on the most often sought-after technical skills and qualities that are considered necessary for graduates to be considered work-ready, in a new wider approach including non-technical skills such as networking (Bridgstock, 2017) and professional identity (Zegwaard, Campbell, \& Pretti, 2017) Employability, finding a job, results from a number of factors such as the foundation of key competences, access to education, availability for participation in training programs, motivation, ability to support and exploit the advantage of continuing learning, recognition of acquired skills, which are crucial to enabling the worker to have a decent job, to be able to manage changes to adopt new technologies and to enter in new markets. In addition, you must have the ability for networking, self-promotion skills for promoting yourself in the job market, to be able to guide a kind of navigating during your career, and to remain active in your lifetime (ILO, 2013). Additionally, the selection and recruitment of a candidate and hence employability are not just a matter of someone possessing formal qualifications but a more complex and multidimensional process that is generally related to the job search effective process, the appearance, impression and performance of the candidate during the interview process. Approaching the concept of employability through the broadening of the perspective of the graduates is crucial as their views are not yet well known (Jackson 2015; Rospigliosi et al., 2014) and and the results through the understanding of their own perspective strategically affects organizational performance (Wright, Golf \& Moliterno, 2014)

\subsubsection{Literature Review}

\subsubsection{Replies About Employability and Job Find}

In the overall international literature review there are various statements regarding the selection of staff to support that to be employable needs more than having formal qualifications. Such statements are the indices formalities quoted below

"Ultimately what counts in the interview are not so much your skills as your ability to effectively present your skills "(Dimopoulos, 2006)

"Finally who is recruited is not necessarily the one who can do the job, but the one who knows more and better about how to be hired" (Kaul, 1992, p. 32)

"What might distinguish successful from unsuccessful applicants is not the quality of their credentials but rather the quality with which they present their credentials (Brems et al 1995) 
"It is more than knowing where to find vacancies. It's about being able to recognize skills and experience from past positions (paid and unpaid) and being able to sell these to potential employers'. (Beddie et al 2005).

Besides, as another research confirms, the interviewers in the process of evaluating candidates for their suitability for recruitment "rely" more on subjective criteria related to the impressions they make in the interview than on the objective information they have, such as the academic achievement and the relevant work experience. (Kinicki \& Lockwood, 1985, p.123). The skills that employers seek in selecting candidates are more about behavioral attributes and soft skills than formal qualifications. This makes it clear that formal qualifications are often necessary, but not effective and self-sufficient for successful job finding (Johnson \& Burden., 2003). Decisions relating to the recruitment of staff are made on the basis of objective qualifications eg. Job match between person to the job and person to organization fit (Johnson, \& Burden, 2003; Bartram, et al., 1995; Wade \& Kinicki, 1997; Roebken, 2010). Occasionally, impressions created by subjective qualifications influence decisions about recruiting staff considerably more than those of objective qualifications because of the emotional effect (Roebken, 2010). It has been said that employability is different from employment since it is feasible for a candidate to be really 'employable' and capable of undertaking a job, but without being a worker (Jackson, 2014; Holmes, 2013). There is, also, the definition of perceived employability, which is a person's personal view of his or her ability to acquire and maintain a job (Vanhercke et al., 2014, p. 594).

\section{The Importance of Employability Training Courses}

Based on the above, we consider appropriate to investigate the dynamics and value that a candidates' training may have in improving their efficiency in job search, job finding, and interview management process so that they ultimately reinforce the degree of their employability. In addition, a formal candidate is expected to change career and jobs from three to seven times during his professional career (Howard, 2000), which means that attending such training programs on the job search process are overtime valuable and necessary. Besides, in the overall international literature review there are number of suggestions regarding the importance of training candidates' for the effectiveness they can bring to the job search. For example, understanding the job finding process, how to locate open jobs, how to communicate and get in touch with businesses, and ultimately how to better portray one's skills, knowledge and personal attributes is vital both in the short-term and long-term professional horizons of each candidate. .It is especially useful for candidates to take part in training programs on job search, in oral and non-verbal communication in order to get knowledge of them and understand their importance and how to handle them appropriately in order to achieve the desired results. Particularly when they possess the necessary formal qualifications but lack communication skills, the above training programs can be extremely useful. This suggests earlier research (Imada \& Hakel, 1977, p.297, 298). Knowing someone his skills by doing a practical exercise on how to present himself, how to demonstrate self-confidence, enhancing his speaking fluency and improving his appearance can be proved particularly important in his evaluation by the interviewers. It is also proposed for future research on whether an education of candidates in all of the above can really contribute to their employability (Bretz et al., 1993, 
p. 323). When the candidate is prepared for the interview then he / she is much more likely to know in advance what the interviewer is expecting from him / her, he / she will be less stressed and will eventually be able to have better control over the impressive strategies with the result of his / her best performance in the interview (Silvester et al.,2002, p. 74). It is obvious that knowing the candidate in depth and understanding the process of finding a job can be of immediate benefit so that he can design an effective search strategy, overcome the feeling of uncertainty caused by unemployment, or even reduce the psychological load and natural fatigue it causes (Strumpf et al.,1983; Winefield et al., 1991). It has already been shown that participation in training programs on the interview and the preparation for it increases efficiency and performance in interviews in the form of questions in hypothetical situations and hence the acceptance of candidates by the interviewers in situational interviews' (Maurer, et al 2001, p. 716). Thus, an important advantage can be that candidates have learning about how to present themselves and their skills more effectively as well as how they will find and approach potential employers (Bartram, et al., 1995). And this training, how to promote yourself better and more effectively, is something that needs to be started early and can be the subject of education through partnerships between universities and liaison offices on issues such as the proper compilation of a curriculum vitae, a cover letter, networking, career planning and all other issues considered necessary to facilitate the integration of graduates into the labor market (McCorkle, et al., 2003, p.203). Research has shown that the combination of professional career guidance and the development of specific employment skills are a very important strategy (Barrow et al., 2010; Knight \& Yorke, 2003) Job search and career counseling should be in the early stages, preventive rather than repressive, and not necessarily aimed at training for a particular job, but much more in developing general skills,-employability skills of candidates such as communication skills, ability to work together or the development of self esteem and confidence (Beddie et al., 2005). The importance of job search counseling and the interviewing process still highlights a survey and stresses the need for further research on this issue. More specifically, it refers to seven important elements that affect interviewers in their decisions about candidates and which are the appearance of the candidate to be edited, the research that the candidate must do for the company before the interview so as to gather useful information, the on time appearance of the candidate at the scheduled time of the interview, the appropriate use of both oral and non-verbal communication, the correct writing of the curriculum vitae, the availability should be displayed for the job, and finally the actions that the candidate can take, such as writing a brief thank you letter after the interview (Pearson, et al., 1993, p.133 ). Finally, an important organization (ILO) International Labor Organization refers extensively and with emphasis to various forms of job search counseling that may exist and already exist in several countries, whether public or private, and emphasizes with particular emphasis the importance of these training programs to the successful transition of the unemployed into the labor market (ILO, 2006; ILO 2008).

\section{Research Method}

The methodology followed in this research has three stages. In the first stage to study our research questions about the relative contribution that a training program could have on the employability of candidates, a primary field research was conducted. Participants were asked 
through a structured questionnaire first to state the extent to which they agree with specific formalities indicating that their employability is the result of many other parameters beyond qualification and secondly to assess the potential contribution and usefulness of a specialized training program to the process of job search and interview that will help to identify and learn these factors which improve employability. As a stimulus for formulating the questions, we relied on the formulations of (Kaul, 1992; Beddie, et al., 2005) and (ILO, 2013) which show that being able to work is the result of not only having formal qualifications but also of many other factors such as knowing how to effectively search for a job by using existing sources of employment, how to draw up an attractive resume, how to effectively promote yourself, the ability to network, the willingness for continue learning and education as these are recorded as statements in these formalities and are indicative of what a successful job search means. At the same time, in another second survey we conducted at the same time, we considered the employers' views on the process of selection of staff and the possible influence could have a specialized training program of candidates on their hiring decisions during interview process. In particular, we have investigated the extent to which employers or recruiters consider that a trained candidate in job search and interview process would influence their decisions a) to hire him, b) to consider him suitable for the position, and c) to rank him in the short list. The sample of two hundred and sixty people included participants as an employer, staff manager, professional recruitment consultants and executives who are responsible for recruiting workers from different work fields and different geographic areas. The third stage of the research which is underway investigates the real value and contribution of such training through empirical research that has long been conducted on a sample of participants who are either in a job-search status, or have a job but actually want to move to another job position, field. At this stage, we investigate the real value of such training, in which more than hundred and fifty people at the moment were already participated, and will investigate the outcome of this training in enhancing their employability as soon as it is completed in a larger sample. In essence, with this research we will have an effect that will cross-check the candidates' views on the estimated effectiveness of training program before joining training program and after completed it. The current study presents the first stage of these investigations, and the next two will be presented in the next series.

\subsection{Research Questions}

In order to formulate the questions, we have taken into account various research related to either employability or the staff selection interview. So we chose to focus on three versions of results that are the most common success indicators of an interview as evidenced by the majority of the bibliographic review. An employment interview usually has the ultimate goal or often ends in the following: hire or recommendation to hire (Gilmore \& Ferris 1989, p.561, 562; Higgins \& Judge 2004), b) possibility of inviting candidates to a second interview (Burger \& Caldwell., 2000, p. 51-62; Caldwell \& Burger., 1988, p.126; Wei-Chi Tsai, et al., 2005 p.113; Stevens \& Kristof, 1995) and to consider a candidate as suitable for the job position (Kinicki \& Lockwood, 1985; Wei-Chi Tsai, et al., 2005, p.113; Stevens \& Kristof, 1995). Based on these indicators, we have formulated the following question. 
How much do you personally believe that the following formalities in the process of finding a job and in the personnel selection are valid in Greek reality in order a) to be considered suitable for a job? b) To give you a chance for a second interview; and (c) to be hired;

Formalities

i) The person who is finally recruited is not necessarily the one who can do the job, but the one who knows more and better about how to be recruited (Kaul, 1992)

ii) Finding a job is more than knowing where to look for a job. It is the ability to recognize, distinguish skills and experience from previous jobs, and have the ability to 'sell' them to potential employers' (Beddie, et al 2005)

Participants had the opportunity to respond to a Likert Scale answers where $1=$ totally disagree, 2 = disagree strongly, $3=$ neutral, $4=$ strongly agree, $5=$ totally agree

Regarding the contribution of work and interview focused training in employability, we have formulated the following question: To what extent do you think that your training as a candidate specifically in your preparation for job interview and job search will effectively contribute to enhancing or improving employability your; a) increasing your chances of joining the labor market, b) making it easier for you to find a new job? The formulation of the question was made according to studies (McQuaid \& Lindsay, 2005; De Grip et al., 2004) whereby employability means those factors that are capable of changing the possibility of a person entering the labor market, or to make it easier for them to find a new job or to improve their existing job. Participants had the opportunity to respond to a Likert Scale answers where $1=$ totally disagree, $2=$ disagree strongly, $3=$ neutral, $4=$ strongly agree, $5=$ totally agree

As a focused training for the labor market, we have set up a training seminar that includes detailed guidance on job search sources, draw an effective $\mathrm{CV}$ and cover letter, handle interview process enhance presentation skills, handle stress management, effective communication, body language learning, career counseling, personal development and networking advices

Hypothesis 1: There is a positive correlation, a consensus between the formalities on what a successful job search means and the views of the participants on the same subject. In other words, the participants consider that finding a job is not just a result of having qualifications but also of all the other parameters that emerge through these formalities. Employability is therefore not only a result of formal qualifications but also depends on other factors

Hypothesis 2: There is a positive correlation between a focused training in the search and finding process and the expected outcome that it can bring to employability in the view of the participants. In other words, the participants expect that training seminar focused on labor market issues will have positive results. Training thus contributes to improving employability outcomes

\subsection{Statistic Analysis}

In order to present the answers given during the interviews, frequency allocation tables were constructed for each question in the questionnaire. The Spearman correlation coefficient was calculated to investigate the correlation between respondent opinions / attitudes. The checks 
were carried out at a confidence level of 0,05. Analyzes were conducted using IBM SPSS Statistics (IBM SPSS Statistics for Windows, version 19 (IBM Corp., Armonk, N.Y., USA)

\subsubsection{Reliability Analysis}

For the overall extent to which the sample participants agree that the formalities and findings with the selection of staff and the recruitment process are valid in order to be recruited, considered suitable for a job and given them the chance for a second interview, a new index has been created. We called this indicator of readiness, hireability or suitability. The values of this index were calculated for each participant in the sample as the average of the above three grades of agreement. In addition, a new index was created for the assessment of the total contribution of candidates' training, especially in their preparation for job interview and job search, which expected to improve their employability. The index values were calculated for each sample participant as the average of the two grades of contribution that they provided of how to improve employability, in particular, to increase the chances of joining the labor market and to facilitate finding a new job.

Table 1. Reliability analysis

\begin{tabular}{l|c|c}
\hline \multicolumn{1}{c|}{ Indicators } & $\begin{array}{c}\text { Number of } \\
\text { items }\end{array}$ & Cronbach's Alpha \\
\hline Readiness, Hireability, Suitabilty & 3 & 0,858 \\
\hline $\begin{array}{l}\text { Contribution of training to interview and job search } \\
\text { process outcomes }\end{array}$ & 2 & 0,871 \\
\hline
\end{tabular}

The two indicators were tested for their credibility by calculating the Cronbach's alpha factor. The results of the credibility analysis showed that both indicators are reliable with Cronbach's alpha taken values greater than 0.7 , as defined in the literature (table 1)

Table 2. Correlation Analysis

\begin{tabular}{l|l|c|c}
\hline & \multicolumn{3}{|c}{$\begin{array}{l}\text { To what extent do you think that your training as a candidate especially } \\
\text { in your preparation for interview and job search will effectively } \\
\text { contribute to enhancing or improving your employability }\end{array}$} \\
\hline $\begin{array}{l}\text { How much do you agree that } \\
\text { the formalities and findings } \\
\text { with staff selection and job } \\
\text { placement are valid for you? }\end{array}$ & $\begin{array}{l}\text { Increasing your } \\
\text { chances of joining } \\
\text { the labor market? }\end{array}$ & $\begin{array}{c}\text { Making it easier to } \\
\text { find a new job? }\end{array}$ & $\begin{array}{c}\text { Improving the job } \\
\text { position you already } \\
\text { have? }\end{array}$ \\
\hline $\begin{array}{l}\text { In order to be recruited? } \\
\text { To be considered suitable for }\end{array}$ & $0.399(<0.001)$ & $0.360(<0.001)$ & $0.319(<0.001)$ \\
\hline job? & $0.459(<0.001)$ & $0.458(<0.001)$ & $0.418(<0.001)$ \\
\hline $\begin{array}{l}\text { In order to give a chance for } \\
\text { a second interview? }\end{array}$ & $0.371(<0.001)$ & $0.388(<0.001)$ & $0.360(<0.001)$ \\
\hline
\end{tabular}




\subsubsection{Correlation Analysis}

The statistical analysis of the data showed that there is a positive correlation ( $\mathrm{rs}=0.460, \mathrm{p}$ $<0.001$ ) between the sample participants' perceptions of eligibility / suitability and the degree to which they believe that their training as a candidate especially in their preparation for the interview and job search will effectively contribute to enhancing or improving your employability. (Table 2)

\subsection{Research Sample}

In this empirical survey, in order to measure participants' views to what extent they agree with (i) the above-mentioned formalities and (ii) the contribution of education to their employability, we used as a tool a structured questionnaire which was addressed to a sample of (213) two hundred thirteen people, of a postgraduate university graduates', as well as postgraduate students in various courses of Greek educational institutions. Attributes of participants that may affect their employability and are related to demographic or social characteristics such as age, gender, dependency, level of education, etc. are also investigated in this questionnaire. Three hundred (300) questionnaires were distributed and a total of two hundred thirteen (213) of them were gathered fully completed. The questionnaire was distributed over a six-month period in 2018 within the classrooms of the postgraduate study programs, printed one by one, with face to face communication and contact with the participants, postgraduate students. This process was considered as most appropriate first because it provided the opportunity for interaction with the participants and gave the opportunity to provide additional information and clarifications on the questionnaire and the research and secondly had the advantage of gathering a large number of questionnaire replies in a relatively short time property that ensures the homogeneity, validity and relevance of the sample. The questionnaire was addressed to active students of the postgraduate program "Lifelong Learning Sciences", a) Educational Management and Leadership, b) Information Technology and New Technologies in Education of the Department of Educational and Social Policy of University of Macedonia, Department of Banking of Open University Branch of Ioannina, Department of Banking, Insurance and Finance, (ATEI) of Western Macedonia, Department of Taxation and Legislation University of Ioannina and the Department of Accounting and Finance of the University of Thessaly, corresponding postgraduate programs.

The participants in the sample who responded to this research in their work concern a variety of professional sectors from public and private primary and secondary education, as well as from other private and public sector employees and were directors, school heads of the public sector, but also private, self-employed, private sector executives, teachers, men and women, of different ages, different specialists. Participants in the sample came from several cities in the country, such as Larissa, Kozani, Ioannina and Thessaloniki. The sample also included people who were in a job search mode at that time. The questionnaire records and portrays personal assessments, evaluations of participants, as it is customary to apply as a practice in relevant scientific research (Saunders, \& Zuzel, 2010; Yorke \& Knight, 2007). The self employability experience questionnaire (SEQ) has a similar target, with the difference that in these researches the focus is on students' views derived from the experience of their 
participation in a specific curriculum studying the enhancement of their employability

Table 3. Gender of participants in sample

\begin{tabular}{l|c|c}
\hline \multicolumn{1}{c|}{ Gender } & \# of participants & Percentage (\%) \\
\hline Male & 101 & 47,4 \\
\hline Female & 112 & 52,6 \\
\hline Total & 213 & 100,0 \\
\hline
\end{tabular}

The majority of participants in the sample are Female (52.6\%), followed by the percentage of Male (47.4\%), (table 3).

Table 4. Age of participants

\begin{tabular}{c|c|c}
\hline Group of age & \# of participants & Percentage (\%) \\
\hline $18-24$ & 37 & 17,4 \\
\hline $25-34$ & 78 & 36,6 \\
\hline $35-44$ & 58 & 27,2 \\
\hline $45-54$ & 37 & 17,4 \\
\hline $55-64$ & 3 & 1,4 \\
\hline Total & 213 & 100,0 \\
\hline
\end{tabular}

The majority of participants in the sample are aged between 25 and 34 years (36.6\%), followed by the percentage of participants aged 35 to 44 (27.2\%), while the corresponding percentage is the same at the age of 18 to 24 and ages 45 to 54 (17.4\%) (table 4).

Table 5. Educational level of participants

\begin{tabular}{c|c|c}
\hline Educational level & \# of participants & Percentage (\%) \\
\hline $\begin{array}{c}\text { Higher } \\
\text { Education-degree }\end{array}$ & 56 & 26,3 \\
\hline Post graduate degree & 141 & 66,2 \\
\hline PhD & 16 & 7,5 \\
\hline Total & 213 & 100,0 \\
\hline
\end{tabular}

The majority of the sample participants hold a postgraduate degree $(66.2 \%)$, followed by the percentage of the undergraduates $(26.3 \%)$, while there is a percentage of the holders of the doctorate $(7,5 \%)$ (Table 5$)$

Table 6. Employment status*

\begin{tabular}{c|c|c}
\hline $\begin{array}{c}\text { Work } \\
\text { status/profession }\end{array}$ & \# of participants & Percentage (\%) \\
\hline Public Sector & 47 & 25,0 \\
\hline Private Sector & 74 & 39,4 \\
\hline Unemployed & 55 & 29,3 \\
\hline Total & 176 & 100,0 \\
\hline
\end{tabular}

The largest share of the sample participants is employed in the private sector $(39.4 \%)$ 
followed by the percentage of participants declaring unemployed (29.3\%) and the share of the employed in the public sector $(25.0 \%)$ (Table 6$) *$ Of the total sample thirty seven people did not report a profession

\section{Analysis of Results}

Table 7. Level of agreement of the views of the participants with the formalities for employability

To what extent do you agree that the formalities and findings with staff selection and job placement procedure are valid for you in order to get hired

\begin{tabular}{l|c|c}
\hline & Number of Participants & Percentage \% \\
\hline Totally disagree & 3 & 1.4 \\
\hline I strongly disagree & 14 & 6.5 \\
\hline Neither agree, nor disagree & 53 & 24.5 \\
\hline Strongly agree & 101 & 46.8 \\
\hline Totally Agree & 45 & 20.8 \\
\hline Total & 216 & 100.0 \\
\hline
\end{tabular}

The majority of the sample participants strongly agree with the formalities $(46.8 \%)$ and a percentage of $(20.8 \%)$, who totally agrees as well. This means that combined the two results we have a significant percentage of $(67,6 \%)$ of respondents who are strongly or totally agree that formalities occur in order someone to get hired during job placement and recruiting process implying that to be someone employable depends on many other factors besides typical qualifications (Table 7)

Table 8. Level of agreement of the views of the participants with the formalities for employability

To what extent do you agree that the formalities and findings with the selection of staff and the job finding process are valid for you to be considered suitable for a job ?

\begin{tabular}{l|c|c}
\hline & Number of Participants & Percentage \% \\
\hline Totally disagree & 3 & 1.4 \\
\hline I strongly disagree & 13 & 6.0 \\
\hline Neither agree, nor disagree & 61 & 28.2 \\
\hline Strongly agree & 101 & 46.8 \\
\hline Totally Agree & 38 & 17.6 \\
\hline Total & 216 & 100.0 \\
\hline
\end{tabular}

The majority of the sample participants strongly agree with the formalities (46.8\%), and a percentage of $(17,6 \%)$, who totally agrees as well. This means that combined the two results we have a significant percentage of $(64,4 \%)$ of respondents who are strongly or totally agree that formalities occur in order someone to considered suitable during job placement and recruiting process implying that to be someone employable depends on many other factors besides typical qualifications (Table 8 ) 
Table 9. Level of agreement of the views of the sample with the formalities for employability

To what extent do you agree that the formalities and findings with staff selection and job placement procedure are valid for giving you a chance for a second interview?

\begin{tabular}{l|c|c}
\hline & Number of Participants & Percentage \% \\
\hline Totally disagree & 3 & 1.4 \\
\hline I strongly disagree & 15 & 6.9 \\
\hline Neither agree, nor disagree & 84 & 38.9 \\
\hline Strongly agree & 71 & 32.9 \\
\hline Totally Agree & 43 & 19.9 \\
\hline Total & 216 & 100.0 \\
\hline
\end{tabular}

A large percentage of the sample participants strongly agree with the formalities (32.9\%) and a percentage of $(19,9 \%)$, who totally agrees as well. Combining the two results we have a remarkable percentage of $(52,8 \%)$ of respondents who are strongly or totally agree that formalities occur in order someone to be given a chance for second interview during job placement and recruiting process implying that to be someone employable depends on many other factors besides typical qualifications. It is obvious that in this stage of selection which is more in depth process the value of these formalities getting less compared to the previous stages, implying that, the influence of the sense of formalities is less (Table 9).

Table 10. Expected contribution of training to employability

To what extent do you think that your training as a candidate especially in your preparation for interview and job search will effectively contribute to enhance or improve your employability by increasing your chances of joining the labor market?

\begin{tabular}{l|c|c}
\hline & Number of Participants & Percentage $\%$ \\
\hline Totally disagree & 2 & 0.9 \\
\hline I strongly disagree & 9 & 4.2 \\
\hline Neither agree, nor disagree & 56 & 25.9 \\
\hline Strongly agree & 104 & 48.1 \\
\hline Totally Agree & 45 & 20.8 \\
\hline Total & 216 & 100.0 \\
\hline
\end{tabular}

The majority (48.1\%) of the sample participants strongly agree with the expected contribution of training in increasing their chances to join the market employment and a percentage of (20.8\%), who totally agrees as well. This means that combining the two results we have a significant percentage of $(68,9 \%)$ of respondents who are strongly or totally agree with the expected contribution of employability training course by increasing their chances to join labor market implying the significance of such training programs (Table 10) 
Table 11. Expected contribution of training to employability

To what extent do you think that your training as a candidate especially in your preparation for an interview and job search will effectively contribute to enhancing or improving your employability by finding a new job?

\begin{tabular}{l|c|c}
\hline & Number of Participants & Percentage \% \\
\hline Totally disagree & 2 & 0.9 \\
\hline I strongly disagree & 11 & 5.1 \\
\hline Neither agree, nor disagree & 56 & 25.9 \\
\hline Strongly agree & 106 & 49.1 \\
\hline Totally Agree & 41 & 19.0 \\
\hline Total & 216 & 100.0 \\
\hline
\end{tabular}

The majority $(49.1 \%)$ of the sample participants strongly agree with the expected contribution of training in finding a new job and a percentage of (19\%), who totally agrees as well. This means that combining the two results we have a significant percentage of $(68,1 \%)$ of respondents who strongly or totally agree with the expected contribution of employability training course by increasing their chances to find a new job implying the significance of such training programs (Table 11)

\section{Discussion}

We examined the views of graduates and the extent to which they agree that their employability for the Greek case is not only dependent on their formal qualifications but also on other additional factors as they were mentioned in the statements we used in our research. The majority of participants agree with the formalities regarding job find, confirming through them the conclusion, that employability depends to a great extent not only on the possession of qualifications but also on other important factors such as continuing learning, networking, self presentations skills, soft skills, labor market knowledge, which are consistent with other surveys (ILO, 2013; Kaul, 1992, p.32; Beddie et al., 2005). We examined also the view of graduates and the extent to which they agree that a relative training in employment issues could help them and contribute to successful employment outcomes and particularly by increasing their chances to join for first time labor market, as well as to improve their employability by helping them to find a new job. Participants agree to a large extent with the necessity and expected usefulness of training on employability which is consistent with the research (Imada \& Hakel, 1977; Bretz et al.,1993; Silvester et al., 2002; Maurer, et., al 2001; Bartram, et al., 1995; McCorkle, et al., 2003; Beddie, et al., 2005; Pearson, et al., 1993; ILO, 2006; ILO 2008, ILO, 2013). Since employability is influenced by many other factors, except of formal qualifications, and a focused training in relevant subjects, is expected to contribute to the understanding and exploitation of these factors, thus it is concluded that the organization and implementation of such training programs are not only useful but also necessary to improve the employability ratio of the candidates 


\section{Conclusions and Suggestions}

\subsection{Best Practices. Embedding Consulting and Mentoring Programs Through HEI}

Research has shown that the combination of professional career guidance and the development of specific employment skills are a very important strategy (Barrow, et al 2010; Yorke \& Knight, 2007). The concept of employment must be very 'specific' for students, employers and universities (Moore, 2009). Graduates become more adept at their employability when their trainers support them in developing a profile, and a set of achievement recording properties (Yorke \& Knight, 2007; Oliver, 2013; Jing, Patel, \& Chalk, 2011). Another effective strategy is to establish mentoring networks among successful graduates in job market and active students who are potential employees (Jing, Patel, \& Chalk, 2011). Lastly, in the future, universities should support graduates to participate in electronic social media tools for continuous communication and search, for new jobs (Barrow, et al., 2010; Jing, Patel, \& Chalk, 2011) From these strategies, the development of a portfolio of graduate characteristics is considered to be the predominant one, and the second in the series is the mentoring strategies and the career counseling. (Kinash, et al.,2014). All of these strategies can be parts of a specialized training program for graduates successfully transition to employment which universities and other stake holders' witch each one can take over contributing to such a crucial issue

\subsection{Research Contribution}

The contribution of this research lies in the fact that it highlights the value of training to prepare students for the labor market, making graduates more employable and providing useful guidance to those who formulate similar employment and training policies. Employment training courses considered extremely important for positive job search outcomes according to graduates views of our sample participants. In this respect, the present study assessing the contribution of training to employability on behalf of graduates view is interesting as a matter of investigation. Further research could focus on particular actual results of such training in groups of job seekers. The contribution of current research is to boost employability stake holders such as universities, education centers and institutes, labor ministry agencies to undertake responsibility and prior actions for organizing relative training programs

\section{References}

Barrow, R., Behr, C., Deacy, S., McHardy, F., \& Tempest, K. (2010). "Embedding Employability into a Classics Curriculum: The Classical Civilisation Bachelor of Arts Programme at Roehampton University", Arts and Humanities in Higher Education: An International Journal of Theory, Research, and Practice, Thousand Oaks, California, pp. 339-352. https://doi.org/10.1177/1474022209350294

Bartram, D., Lindley, P. A., Marshall, L., \& Foster, J. (1995). The recruitment and selection of young people by small businesses. Journal of Occupational and Organizational Psychology, 68(4), 339. https://doi.org/10.1111/j.2044-8325.1995.tb00592.x 
Beddie, F., Lorey, B., \& Pamphilon, B. (2005).Enhancing career development: the role of community based career guidance for disengaged adults. NCVER, Australian Government.

Brems, C., Lampman, C., \& Johnson, M. E. (1995). Preparation of applications for academic positions in psychology. American Psychologist, 50, 533-537. https://doi.org/10.1037/0003-066X.50.7.533

Bretz, Jr., Robert, D., Rynes, S. L., \& Gerhart, B. (1993). Recruiter Perceptions of Applicant Fit: Implications for Individual Career Preparation and Job Search Behavior. Journal of Vocational Behavior, 43(3), 310-327. https://doi.org/10.1006/jvbe.1993.1050

Bridgstock, R. (2017). The university and the knowledge network: A new educational model for Twenty-first Century learning and employability. In M. Tomlinson \& L. Holmes (Eds), Graduate employability in context (pp.339-358). London: Palgrave Macmillan. https://doi.org/10.1057/978-1-137-57168-7_16

Burger, J. M., \& Caldwell, D. F. (2000). Personality, Social, Activities, Job Search Behavior and Interview Success: Distinguishing Between PANAS Trait Positive Affect and NEO Extraversion. Motivation and Emotion, 24(1). https://doi.org/10.1023/A:1005539609679

Caldwell, D. F., \& Burger, J. M. (1988). Personality Characteristics of Job Applicants and Success in Screening Interviews. Personnel Psychology 51. https://doi.org/10.1111/j.1744-6570.1998.tb00718.x

Davies, L. (2000). Why kick the 'L' out of 'LEarning? The development of students' employability skills through part-time working. Education + Training, 42(8), 436-444. https://doi.org/10.1108/00400910010379961

De Grip, A., Van Loo, J., \& Sanders, J. (2004). The industry employability index: taking account of supply and demand characteristics. Int Labour Rev, 143(3), 211-233. https://doi.org/10.1111/j.1564-913X.2004.tb00269.x

Dimopoulos, A. (2006). Labor Market. 'Conquer the position you deserve'. Ziti publications, ISBN 960-456-035-2, ISBN-13 978-960-456-035-6

Gilmore, D. C., \& Ferris, G. R. (1989). The Effects of Applicant Impression Management Tactics on Interviewer Judgments. Journal of Management, 15(4), 557-564. https://doi.org/10.1177/014920638901500405

Higgins, C. A., \& Judge, T. A. (2004). The Effect of Applicant Influence Tactics on Recruiter Perceptions of Fit and Hiring Recommendations: A Field Study. Journal of Applied Psychology, 89(4), 622-632. https://doi.org/10.1037/0021-9010.89.4.622

Holmes, L. M. (2013). Competing Perspectives on Graduate Employability: Possession, Position or Process? Studies in Higher Education, 38(4), 538-54. https://doi.org/10.1080/03075079.2011.587140

Howard, M. (2000). Happily married to the company: in an era of job hopping. Some workers still never leave. The Richumond Times Dispach, July 31, 2000, Metro business, 
D-14. https://doi.org/10.1016/S0262-1762(00)88858-6

Imada, A. S., \& Hakel, M. D. (1977). Influence of Nonverbal Communication and Rater Proximity on Impressions and Decisions in Simulated Employment Interviews. Journal of Applied Psychology, 62(3), 295 - 300. https://doi.org/10.1037/0021-9010.62.3.295

International Labour Organization, ILO. (2004). Human Resources development and training, Report IV (2B), International Labour Conference, 92nd Session.

International Labour Organization, ILO. (2006). Ellen Hansen. Career Guidance. A resource handbook for low- and middle-income countries. ISBN: 92-2-118376-1 (web pdf).

International Labour Organization, ILO. (2008). Resolution on skills for improved productivity, employment growth and development. 97th Session the International Labour Conference.

International Labour Organization, ILO. (2013). Enhancing youth employability: What? Why? and How? Guide to core work skills -HRD Recommendation 195, 2004; this was reinforced in the Resolution of Youth Employment 2005.

Jackson, D. (2014). Business Graduate Performance in Oral Communication Skills and Strategies for Improvement. The International Journal of Management Education, 12(1), 22-34. https://doi.org/10.1016/j.ijme.2013.08.001

Jackson, D. (2015). Employability skill development in work-integrated learning: Barriers and best practice. Studies in Higher Education, 40(2), 350-367. https://doi.org/10.1080/03075079.2013.842221

Jing, Y., Patel, P., \& Chalk, P. (2011).Facilitating the Impact of Graduates on Student Employability, Innovations in Teaching \& Learning in Information \& Computer Sciences, Higher Education Academy's Subject Centre for Information \& Computer Sciences (HEA-ICS), Ulster, United Kingdom, pp. 23-31. https://doi.org/10.11120/ital.2011.10020023

Johnson, S., \& Burden, T. (2003). Young people, employability and the induction process. Joseph Rowntree Foundation, Policy Research Institute, Leeds Metropolitan University 2003.

Kaul, P. A. (1992). Getting the job. Association Management, 44(11), 32- 38, 93-94.

Kinash, S., Crane, L., Schulz, M., Dowling, D., \& Knight, C. (2014). Improving graduate employability: Strategies from three Universities. Ireland International Conference on Education (IICE).

Kinicki, A. J. \& Lockwood, C. A. (1985). The Interview Process: An Examination of Factors Recruiters Use in Evaluating Job Applicants. Journal of Vocational Behavior, 26, 117-125. https://doi.org/10.1016/0001-8791(85)90012-0

Kitchen, P. J. (1994). Self- marketing is easily taught, but hard to learn. Marketing News 28(18), 4- 35.

Knight, T. P., \& Yorke, M. (2003). Assessment, Learning and Employability, Open University 
Press, England.

Maurer, T. J., Solamon, J. M., Andrews, K. D., \& Troxtel, D. D. (2001). Interviewee coaching, preparation strategies and response strategies in relation to performance in situational employment interviews: An extension of Maurer, Solamon, and Troxtel (1998). Journal of Applied Psychology, 86, 709-717. https://doi.org/10.1037//0021-9010.86.4.709

McCorkle, D. E., Alexander, J. F., Reardon, J., \& Kling, N. D. (2003). Developing Self-Marketing Skills: Are Marketing Students Prepared for the Job Search? Journal of Marketing Education, 25(3), 196-207. https://doi.org/10.1177/0273475303257517

McQuaid, R. W., \& Lindsay, C. (2005). The concept of employability: transcending the orthodoxies of supply and demand? Urban Studies, 42(2), 197-219. https://doi.org/10.1080/0042098042000316100

Moore, P. (2009). 'UK Education, Employability, and Everyday Life', Journal for Critical Education Policy Studies, The Institute for Education Policy Studies, United Kingdom, pp. 242-274.

Nilsson, P. A., \& Ripmeester, N. (2016). International Student Expectations: Career Opportunities and Employability. Journal of International Students, 6(2), 614-631.

Oliver, B. (2013). Graduate attributes as a focus for institution-wide curriculum renewal: innovations and challenges, Higher Education Research \& Development, 32(3), 450-463. https://doi.org/10.1080/07294360.2012.682052

Pearson, M., Murphy, M., \& Runyan, S. (1993). Applied H.R.M. Research, 4(2), 126-136.

Pollock, A. (2014). Student employability is a necessity, not a choice. Expertise in Labour Market Mobility. Retrieved from http://www.labourmobility.com/student-employability-necessity-choice/

Roebken, H. (2010). Similarity attracts: An analysis of recruitment decisions in academia. Educational Management Administration \& Leadership, 38(4), 472-486. https://doi.org/10.1177/1741143210368264

Rospigliosi, A. P., Greener, T. B. S., \& Sheehan, M. (2014). Human Capital or Signalling, Unpacking the Graduate Premium. International Journal of Social Economics, 41(5), 420-32. https://doi.org/10.1108/IJSE-03-2013-0056

Rowe, A. D. (2017). Developing graduate employability skills and attributes: Curriculum enhancement through work-integrated learning Asia-Pacific Journal of Cooperative Education, Special Issue, 18(2), 87-99.

Saunders, V., \& Zuzel, K. (2010) Evaluating Employability Skills: Employer and Student Perceptions, Bioscience Education, 15(1), 1-15. https://doi.org/10.3108/beej.15.2

Silvester, J. A., Fiona, M-G., Neil, R. A., \& Afandi, R. M. (2002). Locus of control, attributions and impression management in the selection interview. Journal of Occupational and Organizational Psychology, 75, 59-76. https://doi.org/10.1348/096317902167649 
Stevens, C. K., \& Kristof, A. L. (1995). Making the right impression; A field study of applicant impression management during job interviews. Journal of Applied Psychology, 80, 587-606. https://doi.org/10.1037/0021-9010.80.5.587

Strumpf, S. A., Colarelli, S. M., \& Hartman, K. (1983). Development of the Career Exploration Survey (CES). Journal of Vocational Behavior, 35, 254-269.

Teichler, U. (1998). The transition from higher Education to employment in Europe. Higher Education in Europe, 23(4), 535-558. https://doi.org/10.1080/0379772980230411

Teichler, U. (2000). Graduate employment and work in selected European countries. European Journal of Education, 35(2), 141-156. https://doi.org/10.1111/1467-3435.00013

Vanhercke, D. N., Cuyper, E. P., \& De Witte, H. (2014). Defining Perceived Employability: A Psychological Approach. Personnel Review, 43(4), 592-605. https://doi.org/10.1108/PR-07-2012-0110

Wade, K., \& Kinicki, A. (1997). Subjective applicant qualifications and interpersonal attraction as mediators within a process model of interview selection decisions. Journal of Vocational Behavior, 50(1), 23-40. https://doi.org/10.1006/jvbe.1996.1538

Wei-Chi, T., Chien-Cheng, C., \& Su-Fen, C. (2005). Exploring Boundaries to the Effects of Applicant Impression Management Tactics in Job Interviews. Journal of Management, 31(1), 108-124. https://doi.org/10.1177/0149206304271384

Wickramasinghe, V., \& Perera, L. (2010). 'Graduates', University Lecturers' and Employers' Perceptions towards Employability Skills'. Education + Training, 52(3), 226-244. https://doi.org/10.1108/00400911011037355

Winefield, A. H., Winefield, H. R., Tiggemann, M., \& Goldney, R. D. (1991). A longitudinal study of the psychological effects of unemployment and unsatisfactory employment on young $\begin{array}{lllll}\text { adults. Journal of } & \text { Applied } & \text { Psychology, } & 76, & \text { 424-431. }\end{array}$ https://doi.org/10.1037/0021-9010.76.3.424

Wright, P. M., Coff, R., \& Moliterno, T. P. (2014). Strategic Human Capital Crossing the Great Divide. Journal of Management, 40(2), 353-70. https://doi.org/10.1177/0149206313518437

Yorke, M., \& Knight, P. (2007). Evidence-informed pedagogy and the enhancement of student employability. Teaching in Higher Education, 12(2), 157-170. https://doi.org/10.1080/13562510701191877

Zegwaard, K. E., Campbell, M., \& Pretti, T. J. (2017). Professional identities and ethics: The role of work integrated learning in developing agentic professionals. In T. Bowen \& $\mathrm{M}$. Drysdale (Eds.), Work-integrated learning in the 21st century: Global perspectives on the future international perspectives on education and society (pp. 145-160). Bingley, UK: Emerald Publishing Limited. https://doi.org/10.1108/S1479-367920170000032009 
Glossary

SEQ: Self employability experience questionnaire

ATEI: Higher Technical Educational Institutes

ILO: International Labor Organization

HEI: Higher Educational Institutes

\section{Copyright Disclaimer}

Copyright for this article is retained by the author(s), with first publication rights granted to the journal.

This is an open-access article distributed under the terms and conditions of the Creative Commons Attribution license (http://creativecommons.org/licenses/by/4.0/). 